Original Research Paper

\title{
Biologi Reprodksi Ikan Kembung (Rastrelliger brachysoma Bleeker, 1851) di Teluk Staring, Sulawesi Tenggara
}

\author{
Sudarno Sudarno ${ }^{1}$, La Anadi ${ }^{2}$, Asriyana Asriyana ${ }^{3}$ \\ ${ }^{1}$ Program Studi Ilmu Perikanan, Program Pasca Sarjana Universitas Halu Oleo, Kendari, Sulawesi Tenggara, Indonesia \\ ${ }^{2}$ Program Studi Perikanan Tangkap, FPIK Universitas Halu Oleo Kendari, Sulawesi Tenggara, Indonesia \\ ${ }^{3}$ Program Studi Manajemen Sumberdaya Perairan, FPIK Universitas Halu Oleo Kendari, Sulawesi Tenggara, Indonesia
}

\begin{abstract}
Riwayat artikel
Received : 3 Februari 2020

Revised : 18 Februari 2020

Accepted : 20 Februari 2020

Published : 21 Februari 2020

*Corresponding Author:

Asriyana,

Jurusan Manajemen

Sumberdaya Perairan, FPIK

Universitas Halu Oleo Kendari

Email: asriyana@uho.ac.id
\end{abstract}

\begin{abstract}
Abstrak: Biologi reproduksi suatu organisme merupakan salah satu informasi penting dalam upaya pengelolaan sumberdaya perairan. Penelitian biologi reproduksi ikan kembung (Rastrelliger brachysoma) di Teluk Staring, Sulawesi Tenggara dilakukan dari bulan Maret sampai Juli 2018. Penelitian ini bertujuan untuk menganalisis biologi reproduksi ikan kembung yang meliputi tingkat kematangan gonad (TKG), indeks kematangan gonad (IKG), dan ukuran pertama kali matang gonad. Koleksi ikan menggunakan alat tangkap jaring insang permukaan bermata jaring 2 dan 2 1/4 inci. Kematangan gonad ikan diamati berdasarkan morfologi gonad yaitu bentuk, warna, dan bobot gonad. Sebanyak 215 individu ikan kembung tertangkap dengan kisaran panjang 206-297 mm dan bobot 110,0-366,0 g. IKG ikan jantan dan betina tertinggi ditemukan saat bulan Maret (1,80 dan 2,22) dan Mei (1,77 dan 1,91). Ukuran pertama kali matang gonad ikan jantan dan betina terjadi saat berukuran panjang $247 \mathrm{~mm}$ dan $239 \mathrm{~mm}$. Penelitian ini mengindikasikan bahwa puncak pemijahan ikan kembung ( $R$. brachysoma) di perairan Teluk Staring terjadi saat bulan Maret dan Mei.
\end{abstract}

Kata kunci: Reproduksi, kembung, musim pemijahan, Teluk Staring, Sulawesi Tenggara

Abstract: Reproduction biology of organism is one of information for aquatic
resources management. Research on the biology of short mackerel
reproduction (Rastrelliger brachysoma) in Gulf of Staring, Southeast Sulawesi
was conducted from March to July 2018. The objective of this research was to
describe aspects of the reproductive biology of short mackerel such as gonadal
maturation, gonadosomatic index, and length at first maturity (Lm50). Fish
collection was done using gillnets (with mesh sizes of 2 and $21 / 4$ inches). The
gonadal maturation of fish was determined morphologically by comparing the
shape, size, color, and gonad weight. A total of 215 individual fish were caught
with ranging $206-297$ mm in length and $110.0-366.0$ g in weight. The
gonadosomatic index of male and female were found in March (1.80 and 2.22 )
and May (1.77 and 1.91 ), while length at first maturity (Lm50) of male and
female were 239 mm and 247 mm, respectively. This research indicates that
the peak of short mackerel spawning in Gulf of Staring waters occurred during
March and May.

Keywords: Reproduction; short mackerel; spawning season; Gulf of Staring, Southeast Sulawesi

\section{Pendahuluan}

Ikan kembung, Rastrelliger brachysoma Bleeker, 1851 (Pisces: Scombridae) atau short mackerel merupakan salah satu ikan pelagis kecil. Ikan ini hidup di perairan pantai atau oseanis; dapat mencapai ukuran 100 cm dan tersebar luas di bagian tengah Indo-Pasifik (Peristiwady, 2006). Salah satu wilayah sebaran ikan ini di Sulawesi Tenggara adalah perairan Teluk Staring. Teluk Staring merupakan salah satu teluk yang terletak di Kabupaten Konawe Selatan, Provinsi Sulawesi Tenggara. Beberapa aktivitas perikanan dapat dijumpai 
di perairan tersebut seperti kegiatan budidaya karamba jaring apung dan jaring tancap, budidaya rumput laut, ikan hias serta kegiatan penangkapan ikan pelagis dan demersal.

Ikan kembung sering ditangkap dengan beberapa alat tangkap, salah satunya adalah jaring insang. Jaring insang merupakan alat tangkap dengan tingkat selektivitas yang rendah (Arami \& Mustafa, 2010; Asriyana et al., 2020). Selain beragamnya hasil tangkapan sampingan (by-catch), juga sering tertangkap ikan kembung yang sedang matang gonad. Jika hal tersebut berlangsung terus menerus maka bukan tidak mungkin akan mengganggu rekrutmen ikan tersebut di alam karena ikan tidak berkesempatan melakukan pemijahan minimal satu kali dalam siklus hidupnya. Kondisi tersebut dikhawatirkan akan berdampak terhadap penurunan stok populasi baik dari segi ukuran maupun jumlah.

Kegiatan perikanan tangkap yang tidak ramah lingkungan tersebut dapat memengaruhi biologi reproduksi suatu jenis ikan di perairan seperti yang dilaporkan Reynolds et al. (2001) dan de Graaf et al. (2003). Biologi reproduksi suatu organisme penting diketahui dalam upaya pengelolaan sumberdaya perairan. Informasi mengenai perkembangan gonad dan ukuran pertama kali matang gonad dapat digunakan untuk memprediksi waktu dan tempat pemijahan suatu sumberdaya dalam menjamin keberlanjutannya di perairan.

Penelitian tentang ikan kembung $(R$. brachysoma) telah banyak dilakukan di beberapa lokasi (Collette \& Nauen, 1983; Suyama et al., 2000; Noranarttragoon, 2005; Sritakon et al., 2011; Juan-
Jordá et al., 2013; Senarat et al., 2015; Senarat et al., 2017; Kantun et al., 2018; Zamroni \& Ernawati, 2019), namun penelitian sejenis belum pernah dilakukan di perairan Teluk Staring, Sulawesi Tenggara. Setiap lokasi memiliki karakteristik fisik kimiawi yang berbeda sehingga sumberdaya perairan akan memberikan respon yang berbeda terhadap kondisi tersebut, tidak terkecuali ikan kembung yang hidup di Teluk Staring. Kondisi tersebut diduga berimplikasi terhadap kondisi biologi reproduksi ikan kembung di perairan ini. Oleh karena itu penelitian ini bertujuan untuk menganalisis biologi reproduksi ikan kembung di perairan Teluk Staring Sulawesi Tenggara.

\section{Bahan dan Metode}

\section{Waktu dan tempat}

Penelitian dilaksanakan dari bulan Maret sampai Juli 2018 di perairan Teluk Staring, Sulawesi Tenggara (Gambar 1). Pengambilan sampel dilakukan setiap bulan selama lima bulan penelitian. Titik pengambilan sampel ditentukan secara acak pada empat titik dengan pertimbangan keterwakilan daerah penangkapan populasi ikan kembung (Tabel 1).

Sampel ikan kembung ditangkap dengan menggunakan jaring insang permukaan bermata jaring 2 inci dan $2 \frac{1}{4}$ inci. Sampel ikan yang tertangkap kemudan dikumpulkan ke dalam cool box untuk dianalisis lebih lanjut di Laboratorium Fakultas Perikanan dan Ilmu Kelautan Universitas Halu Oleo. Di laboratorium, ikan sampel diukur panjang totalnya menggunakan mistar berketelitian $1 \mathrm{~mm}$ dan ditimbang bobotnya menggunakan timbangan digital dengan ketelitian $0,1 \mathrm{~g}$.

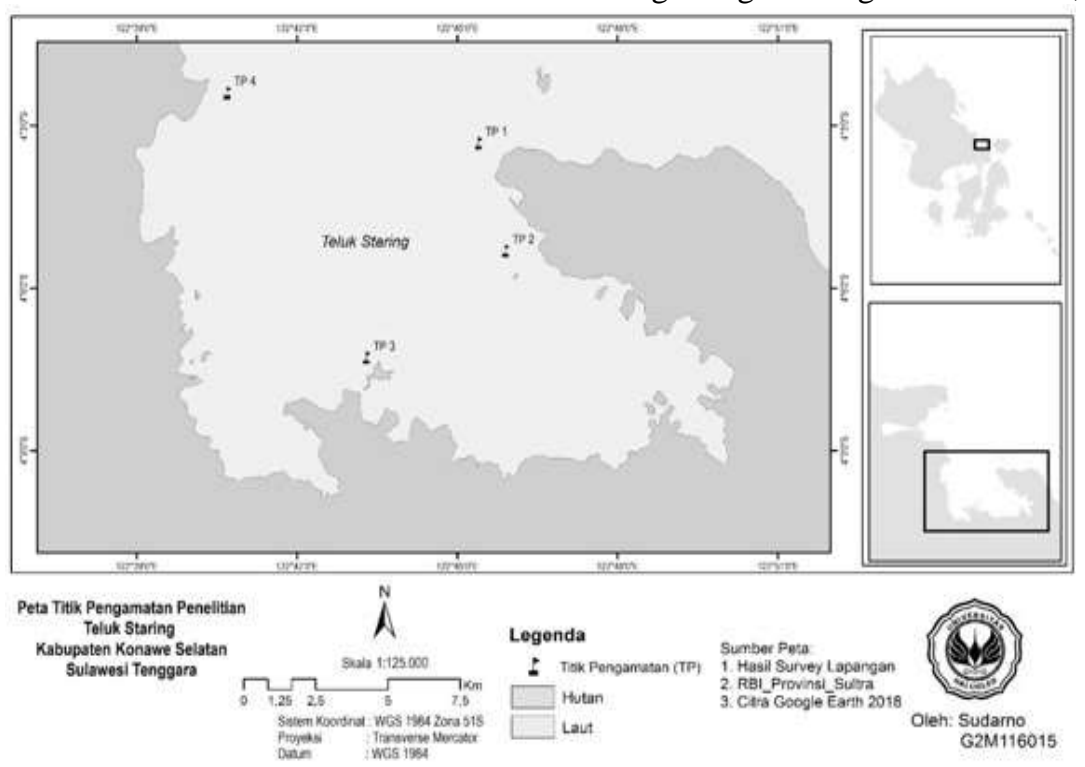

Gambar 1. Peta lokasi penelitian di perairan Teluk Staring 
Tabel 1. Lokasi penangkapan ikan dan titik koordinat.

\begin{tabular}{|c|c|c|}
\hline Lokasi & Daerah penangkapan ikan & Titik koordinat \\
\hline $\mathrm{I}$ & Perairan Tanjung Gomo & $4^{0} 3^{\prime} 18,64^{\prime \prime} L S$ dan $122^{0} 45^{\prime} 22,58^{\prime \prime} \mathrm{BT}$ \\
\hline II & Perairan Tanjung Lemo & $4^{0} 5^{\prime} 19,41^{\prime \prime} \mathrm{LS}$ dan $122^{0} 45^{\prime} 54,57^{\prime \prime} \mathrm{BT}$ \\
\hline III & Perairan Pulau Wawosunggu & $4^{0} 7^{\prime} 18,44^{\prime \prime} \mathrm{LS}$ dan $122^{\circ} 43^{\prime} 18,03$ ' BT \\
\hline IV & Perairan Tanjung Tiram & $4^{0} 2^{\prime} 22,09^{\prime \prime} \mathrm{LS}$ dan $122^{\circ} 40^{\prime} 34,74^{\prime \prime} \mathrm{BT}$ \\
\hline
\end{tabular}

Sampel ikan kemudian dibedah untuk membedakan antara jantan dan betina, jantan ditandai dengan gonad yang berwarna putih dan betina ditandai dengan gonad yang berwarna kuning. Tingkat kematangan gonad (TKG) ditentukan secara morfologi dengan melihat bentuk, warna, dan perkembangan isi gonad berdasarkan Ganga (2010). Selanjutnya gonad dikeluarkan dari tubuh ikan dan ditimbang dengan timbangan berketelitian 0,01 g. Indeks kematangan gonad didasarkan pada bobot gonad dengan bobot tubuh ikan seperti yang dikemukakan Suyama et al. (2000); Asriyana \& La Sara (2013).

Ukuran pertama kali matang gonad ditentukan dengan menyesuaikan fraksi ikan yang matang terhadap interval panjang ikan berdasarkan prosedur King (1995); Rao \& Sharma (1984); Offem et al. (2008); Ghosh et al. (2016). Persentase kumulatif 50\% adalah titik estimasi ukuran pertama matang gonad ikan yang diteliti. Ikan matang yang dimaksud dan dijadikan persentase kumulatif dalam penentuan ukuran pertama matang gonad ini adalah ikan yang telah masuk dalam kategori TKG III, IV, dan V.

\section{Hasil dan Pembahasan}

\section{Sebaran Ukuran}

Selama penelitian tertangkap sebanyak 215 individu ikan kembung yang terdiri dari 99 individu jantan dan 116 individu betina. Ikan jantan memiliki kisaran panjang 206-296 mm dan bobot 115,0-311,0 g, sementara ikan betina memiliki panjang 207-287 $\mathrm{mm}$ dan bobot 110,0-366,0 g. Kisaran ukuran panjang 237,1-247,4 mm merupakan ukuran yang dominan baik ikan jantan maupun betina $(26,72 \%$ dan $19,19 \%)$.

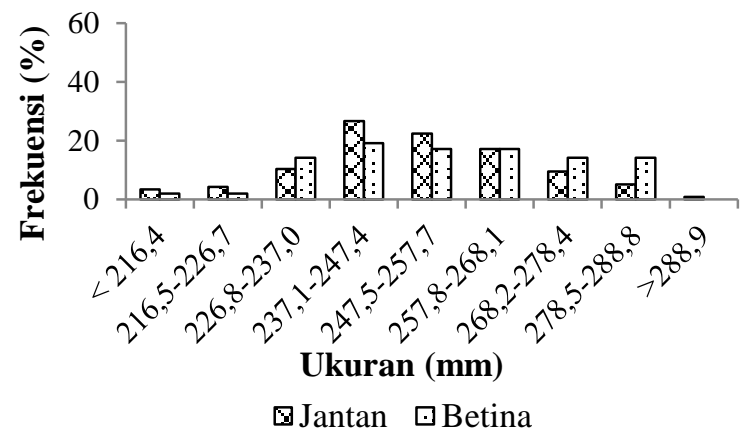

Gambar 2. Sebaran ukuran ikan kembung jantan dan betina di perairan Teluk Staring
Tertangkapnya ikan kembung pada ukuran 206$296 \mathrm{~mm}$ tersebut berkaitan dengan penggunaan alat tangkap jaring insang dengan mesh size 2 dan 2 1/4. Hal yang sama juga dilaporkan pada ikan kembung lelaki $(R$. kanagurta) yang tertangkap pada ukuran 220-240 mm (Bhendarkar et al., 2014) di perairan Ratnagiri Coast, India. Tidak selamanya ikan kembung memiliki sebaran ukuran yang sama di beberapa lokasi (Tabel 2). Ukuran ikan yang ditangkap sangat dipengaruhi oleh alat tangkap yang diterapkan selama kegiatan penangkapan (Erzini et al., 1998); waktu penangkapan yang berbeda, waktu makan, jenis pakan, dan kedalaman operasi penangkapan berkontribusi terhadap ukuran ikan yang ditangkap (Kantun et al., 2014); prilaku biologi ikan (Soria \& Dagorn, 1992; Dewanti et al. 2014).

Tabel 2. Sebaran ukuran ikan kembung, R. brachysoma di beberapa lokasi

\begin{tabular}{cll}
\hline $\begin{array}{c}\text { Sebara } \\
\text { ukuran } \\
(\mathbf{m m})\end{array}$ & \multicolumn{1}{c}{ Lokasi } & \multicolumn{1}{c}{ Pustaka } \\
\hline $140-210(\mathrm{FL})$ & Pantai Utara & Zamroni et al., \\
& Jawa & 2008 \\
$165-263 \mathrm{TL}$ & Teluk Thailand & Sritakon et al., \\
& Selatan & 2011 \\
$95-255 \mathrm{TL}$ & Selat Sunda & Sarasati, 2017 \\
$120-220 \mathrm{FL}$ & Pantai Utara & Zamroni \& \\
& Jawa & Ernawati, 2019 \\
\hline
\end{tabular}

\section{Tingkat Kematangan Gonad}

Tingkat kematangan gonad merupakan tahapan tertentu perkembangan gonad sebelum dan sesudah ikan memijah. Kematangan gonad ikan kembung pada berbagai fase tertera pada Gambar 3 dan 4 .

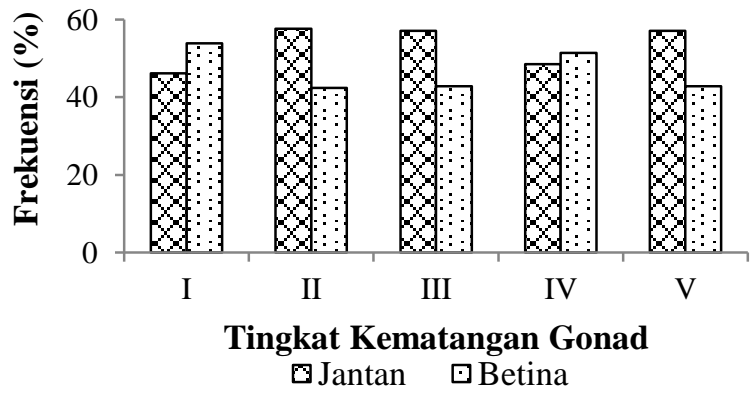

Gambar 3. Kematangan gonad ikan kembung di perairan Teluk Staring 

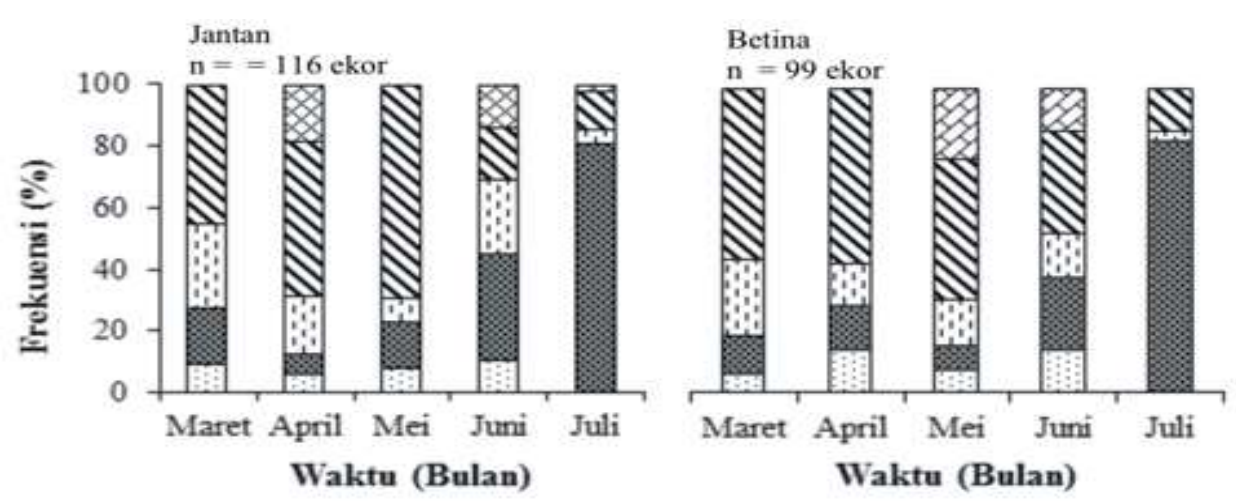

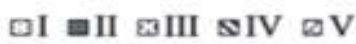

Gambar 4. Kematangan gonad ikan kembung selama penelitian di Perairan Teluk Staring.

Perkembangan gonad ikan jantan dan betina dari TKG I sampai V ditemukan saat penelitian. Hal ini mengindikasikan bahwa ikan kembung yang tertangkap di Teluk Staring merupakan ikan penghuni tetap perairan ini karena semua tahapan siklus hidupnya berada dalam perairan ini. Berbeda dengan ikan kembung yang ditemukan di perairan Teluk Kendari yang hanya menggunakan sebagian waktunya di perairan tersebut (Asriyana et al., 2009), seperti yang juga dilaporkan pada beberapa jenis ikan pelagis kecil lainnya di perairan Lalowaro (Muhajirah et al., 2018), Teluk Kolono (Asriyana et al., 2020). Hal ini diduga berkaitan dengan kelengkapan ekosistem yang ditemukan di perairan Teluk Staring daripada Teluk Kendari. Teluk Staring memiliki ekosistem yang lengkap, dimana ditemukan ekosistem mangrove, lamun, dan terumbu karang (Bappeda Konawe Selatan, 2011), sementara di Teluk Kendari hanya ditemukan ekosistem mangrove (Asriyana et al., 2009). Beberapa jenis ikan pelagis kecil umumnya bersifat sementara di suatu perairan dalam melengkapi siklus hidupnya. Perairan tersebut hanya digunakan sebagai daerah pembesaran, perlindungan, atau daerah pemijahan.

Proporsi TKG II, III, dan V pada ikan jantan lebih besar daripada ikan betina, sebaliknya proporsi TKG I dan IV pada ikan betina lebih besar daripada ikan jantan. Pergeseran TKG merupakan salah satu informasi puncak pemijahan sedang belangsung walaupun pemijahan sepanjang tahun (Prihartini et al., 2007; Oktaviani et al., 2013). Bervariasinya tahapan perkembangan gonad tersebut dipengaruhi oleh laju pertumbuhan individu ikan dan kondisi lingkungan perairan, salah satunya adalah ketersediaan makanan di perairan. Saat perkembangan gonad tersebut, sebagian besar hasil metabolisme tertuju pada perkembangan gonad. Ditemukannya TKG IV selama penelitian baik pada ikan jantan maupun betina mengindikasikan bahwa ikan kembung memijah sepanjang tahun (Gambar 4). Hal yang sama juga dilaporkan Suyama et al. (2000) di perairan Sulawesi
Selatan; Sritakon et al. (2011) di perairan Teluk Thailand. Ikan kembung di perairan tersebut memijah sepanjang tahun dengan dua musim puncak yaitu DesemberFebruari dan Mei-Agustus. Setelah mencapai kematangan, spesies ini mengulangi siklus reproduksi dalam gonad dari tahap perkembangan, pemijahan, kemunduran, dan istirahat (Suyama et al., 2000).

Pematangan gonad pada ikan terjadi dalam dua tahapan yaitu tahap pertumbuhan gonad hingga mencapai kedewasaan kelamin dan tahap pematangan gonad. Tahap pertumbuhan terjadi saat ikan mulai dewasa samapai mencapai dewasa kelamin, sementara tahap pematangan gonad mulai terjadi saat ikan dewasa kelamin dan terus berkembang selama proses reproduksi masih berjalan normal (Lagler at al., 1977; Harvey \& Hoar, 1979; Simanjuntak, 2007). Selama proses reproduksi tersebut, sebagai besar energi hasil metabolisme ikan akan tertuju perkembangan gonad atau pertumbuhan gonadik Effendie, 2002).

\section{Indeks Kematangan Gonad}

Indeks kematangan gonad (IKG) merupakan gambaran perkembangan gonad secara kuantitatif. Nilai indeks kematangan gonad dapat digunakan sebagai media untuk menentukan terjadinya musim pemijahan pada organisme ikan. Variasi nilai IKG ikan kembung selama periode penelitian tertera pada Gambar 5. Variasi nilai IKG tersebut menunjukkan bahwa ada sekelompok ikan yang tidak bertelur secara bersamaan, sehingga perkembangan gonad juga bervariasi. Nilai IKG tertinggi baik ikan jantan maupun betina terjadi saat bulan Maret (1,80 dan 2,22) dan Mei (1,77 dan 1,91). Hal ini mengindikasikan bahwa puncak pemijahan ikan kembung di Teluk Staring terjadi saat bulan Maret dan Mei. Berbeda dengan ikan kembung di Teluk Staring, musim pemijahan ikan kembung di perairan Indramayu dan Teluk Jakarta terjadi saat musim barat (Suwarso \& Hariati, 2003), sementara di perairan pantai Utara Jawa 


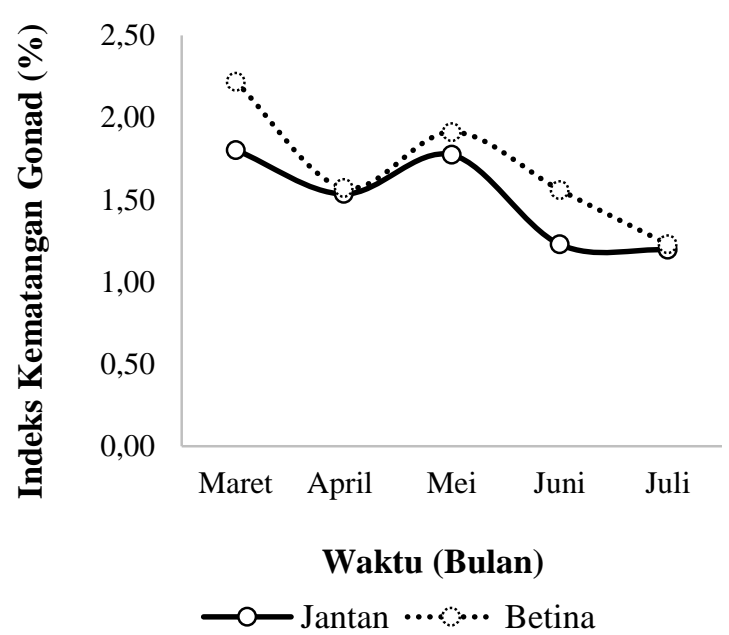

Gambar 5. Indeks kematangan gonad ikan kembung di perairan Teluk Staring

terjadi saat musim timur (Zamroni et al., 2008). Perbedaan musim pemijahan di beberapa lokasi tersebut berkaitan dengan variasi nilai indeks kematangan gonad yang ditemukan pada ikan kembung. Perbedaan musim pemijahan tidak hanya terjadi pada spesies ikan yang sama, namun juga dilaporkan pada beberapa spesies lainnya seperti ikan siro, S. longiceps (Asriyana \& La Sara, 2012); lele laut, Plotosus lineatus (Asriyana et al., 2020).

Tahapan kematangan gonad tertinggi umumnya selalu diikuti oleh peningkatan nilai IKG (Gambar 6). Indeks bertambah besar dan mencapai kisaran maksimum sesaat ikan berpijah dan kembali menurun setelah ikan berpijah. Hal ini berhubungan dengan peningkatan bobot ovarium karena proses vitelogenesis dalam perkembangan gonad dan peningkatan bobot testes karena proses spermatogenesis dan peningkatan volume semen dalam tubulus seminiferi (Asriyana \& La Sara, 2013). Hal yang sama juga dilaporkan pada ikan kembung di perairan Sulawesi Selatan (Suyama et al., 2000). Hal tersebut juga dilaporkan pada beberapa spesies ikan berbeda seperti ikan kurisi, Nemipterus tambuloides (Brojo \& Sari, 2002); ikan motan, Thynnichthys polylepis (Bakhris et al., 2007); kembung lelaki, $R$. kanagurta di perairan Laut Jawa (Nurhakim, 1993), Makassar (Kantun et al., 2018), Barat Aceh (Arrafi et al., 2016); ikan siro Sardinella longiceps (Asriyana \& La Sara, 2013).

Ikan betina mempunyai nilai indek kematangan gonad lebih besar daripada ikan jantan (Gambar 5 dan 6). Pertambahan berat gonad pada ikan betina sebesar 10$25 \%$ dari bobot tubuh dan ikan jantan sebesar $5-10 \%$. Hal ini berhubungan dengan proses vitelogenesis dan spermatogenesis yang terjadi pada gonad. Kondisi demikian juga ditemukan pada ikan kembung di perairan pantai Utara Jawa (Zamroni et al., 2008). Bervariasinya nilai indeks kematangan gonad antara ikan jantan dan betina tersebut disebabkan oleh kelompok ikan yang matang gonad tidak berada di daerah penangkapan (fishing ground), diduga bermigrasi ke daerah pemijahan (spawning ground) dan daerah penangkapan juga merupakan daerah untuk mencari makan (feeding ground) serta pertumbuhan bagi ikan kembung (Suwarso \& Sadhotomo, 1995).

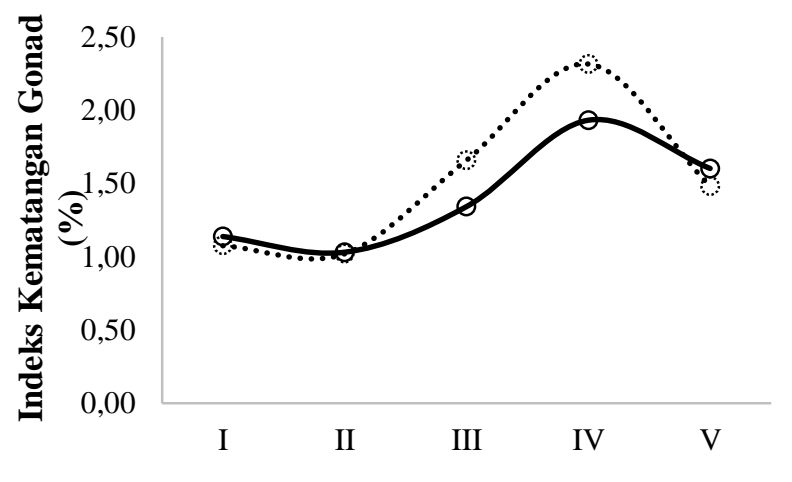

Tingkat Kematangan Gonad

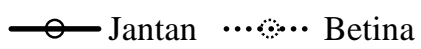

Gambar 6. Hubungan tingkat kematangan gonad dan indeks kematangan gonad ikan kembung di perairan Teluk Staring

\section{Ukuran Pertama Matang Gonad}

Ukuran pertama kali matang gonad $\left(\mathrm{Lm}_{50}\right)$ ikan kembung tertera pada Gambar 7. Ikan jantan pertama mencapai matang gonad saat berukuran panjang $247 \mathrm{~mm}$, sementara ikan betina terjadi saat berukuran panjang 239 $\mathrm{mm}$. Informasi tersebut dapat digunakan sebagai indikator ketersedian stok reproduktif dan waktu ikan yang sudah siap untuk ditangkap dengan menggunakan alat tangkap yang selektif (Najamuddin et al., 2004).

Ukuran pertama matang gonad ikan kembung di Teluk Staring tidak selalu sama dengan ikan spesies sama di lokasi lain seperti yang tertera pada Tabel 3. Perbedaan seks berpeluang menunjukkan ukuran pertama matang gonad berbeda karena perbedaan kecepatan pertumbuhan akibat asupan makanan. Ukuran panjang ikan saat pertama kali matang gonad relatif bervariasi walaupun berasal dari spesies yang sama. Hal ini berkaitan dengan sebaran geografis (Udupa, 1986; Effendie, 2002); perubahan lingkungan terutama suhu (Karna \& Panda, 2011; Beyer et al., 2012); sifat genetik populasi, ukuran dan umur ikan yang menyebabkan perbedaan laju pertumbuhan (Lowe-Mc Connel, 1990; Moresco \& Bemvenuti, 2006); habitat ikan dan makanan (Saud, 2011; Asriyana \& La Sara, 2013; Zaki et al., 2012); dan perbedaan wilayah dan tekanan penangkapan (Reynolds 

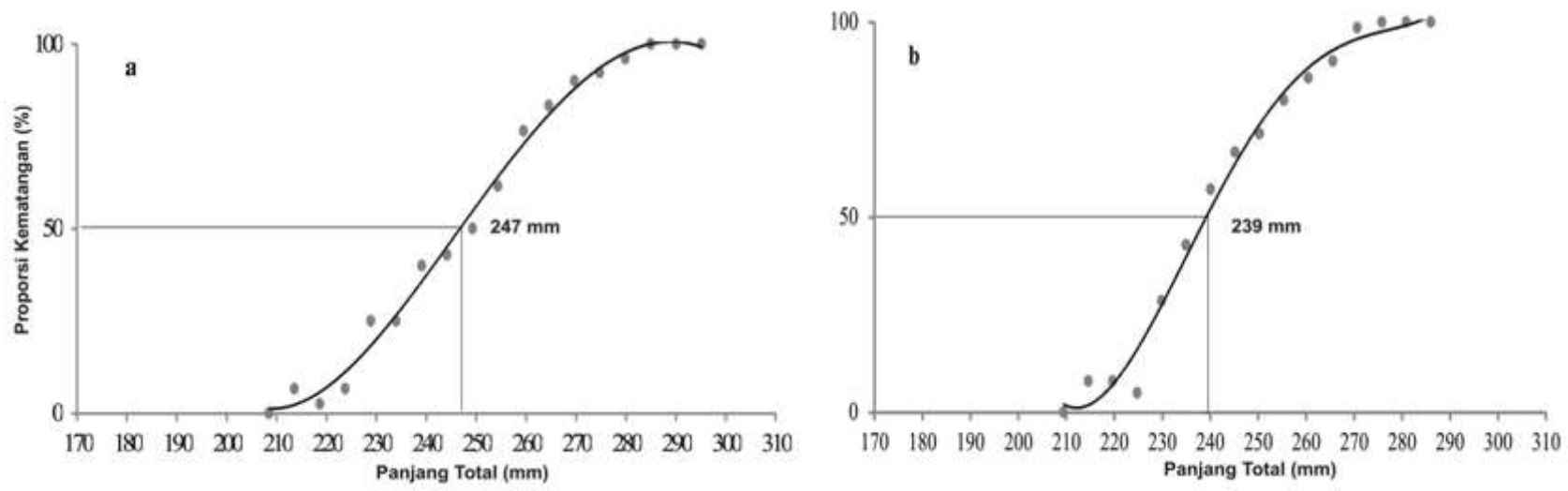

Gambar 7. Estimasi ukuran pertama matang gonad (Lm 50\%) ikan kembung jantan (a) dan betina (b) di Perairan Teluk Staring

Tabel 3. $\mathrm{Lm}_{50}$ ikan kembung di beberapa lokasi

\begin{tabular}{|c|c|c|c|}
\hline Spesies & $\mathbf{L m}_{50}(\mathbf{m m})$ & Lokasi & Pustaka \\
\hline R. brachysoma & $171,0 \mathrm{FL}$ & Laut Jawa & Suwarso \& Hariati (2003) \\
\hline \multicolumn{4}{|l|}{ R. brachysoma } \\
\hline Jantan & $211,0 \mathrm{FL}$ & Pantai Utara Jawa & Suwarso (2010) \\
\hline Betina & 194,0 FL & & \\
\hline Betina & $206,0 \mathrm{TL}$ & & \\
\hline \multicolumn{4}{|l|}{ R. brachysoma } \\
\hline Jantan & $160,2 \mathrm{TL}$ & Gulf Thailand & Sritakon et al. (2011) \\
\hline Betina & $168,4 \mathrm{TL}$ & & \\
\hline R. brachysoma & $164,0 \mathrm{FL}$ & Laut Jawa & Suwarso et al. (2015) \\
\hline R. brachysoma & $169,0 \mathrm{FL}$ & Selat malaka & Ghosh et al. (2016) \\
\hline Rastralliger $\mathrm{sp}$. & $250,0 \mathrm{FL}$ & $\begin{array}{l}\text { Sidangoli Dehe } \\
\text { Halmahera Barat }\end{array}$ & Abubakar et al. (2019) \\
\hline R. brachysoma & $152,1 \mathrm{FL}$ & Pantai Utara Jawa & Zamroni \& Ernawati (2019) \\
\hline \multicolumn{4}{|l|}{ R. brachysoma } \\
\hline Jantan & $247,0 \mathrm{TL}$ & Teluk Staring, & Penelitian ini (2020) \\
\hline Betina & $239,0 \mathrm{TL}$ & Sulawesi Tenggara & \\
\hline
\end{tabular}

et al., 2001; de Graaf et al., 2003). Spesies berbeda mempunyai ukuran berbeda saat matang gonad pertama kali seperti yang dilaporkan pada beberapa spesies ikan lain seperti ikan gurami, Trichogaster pectoralis (Amornsakun et al., 2004); climbing perch, Anabas testudineus (Amornsakun et al., 2005); ikan pelangi merah, Glossolepis incisus (Siby et al., 2009); ikan selais, Ompok hypopthalamus (Simanjuntak, 2007); ikan siro, $S$. longiceps (Asriyana \& La Sara, 2013); ikan lele laut, Plotosus canius (Amornsakun et al., 2018); ikan kembung lelaki, R. kanagurta (Kantun et al., 2018).

\section{Kesimpulan}

Berdasarkan informasi tahapan perkembangan gonad dan nilai indeks kematangan gonad, ikan kembung di Teluk Staring memijah sepanjang tahun dengan puncak pemijahan terjadi saat bulan Maret dan Mei (IKG bulan
Maret $=1,80-2,22$ dan Mei $=1,77-1,91)$. Ukuran ikan kembung layak tangkap di Teluk Staring dapat dilakukan saat ikan berukuran lebih besar dari $247 \mathrm{~mm}$ TL dengan pertimbangan ikan sudah melakukan pemijahan minimal satu kali dalam siklus hidupnya.

\section{Ucapan Terima Kasih}

Penulis mengucapkan terima kasih kepada Program Studi Ilmu Perikanan Pascasajana Universitas Halu Oleo atas seluruh dukungan fasilitas dalam penyelesaian penelitian ini.

\section{Daftar Pustaka}

Abubakar, S., Riyadi, S. \& Irmalita, T. (2019). Pendugaan Ukuran Pertama Kali Matang Gonad Ikan Kembung (Rastralliger $s p$ ) di Perairan Desa 
Sidangoli Dehe Kecamatan Joilolo Selatan Kabupaten Halmahera Barat. Jurnal Biologi Tropis, $\quad 19 \quad$ (1): $\quad 42-51$. http://dx.doi.org/10.29303/jbt.v19i1.1008

Amornsakun, T., Sriwatana, W. \& Promkaew, P. (2004). Some Aspects in Early Life Stage of Siamese Gourami, Trichogasterpectoralis (Regan) larvae. Songklanakarin Journal of Science and Technology, 26(3): 347-356. https://rdo.psu.ac.th/sjstweb/journal/26-

3/06siamese-gourami-fish.pdf

Amornsakun, T., Sriwatana, W., \& Promkaew, P. (2005). Some Aspects in Early Life Stage of Climbing Perch, Anabas testudineus larvae. Songklanakarin Journal of Science and Technology, 27(1): 403418.

https://pdfs.semanticscholar.org/4acb/55781deb4c 1789c8c048cb4ccc1973e4ce7e.pdf

Amornsakun, T., Krisornpornsan, B., Jirasatian, P., Pholrat, T., Pau, T.M. \& bin Hassan, A. (2018). Some Reproductive Biological Aspects of GrayEel Catfish, Plotosus canius Hamilton, 1822 spawner in Pattani Bay, Thailand. Songklanakarin J. Sci. Technol., $40 \quad$ (2): 384-389. https://rdo.psu.ac.th/sjstweb/journal/40-2/40-218.pdf

Arami, H. \& Mustafa, A. (2010). Analisis Selektivitas Gillnet yang Dioperasikan di Perairan Lentea, Kecamatan Kaledupa Selatan Kabupaten Wakatobi. Warta Iptek, 18(1): 38-43. https://adoc.tips/analisis-selektivitas-gillnet-yangdioperasikan-di-perairan-.html

Arrafi, M., Azmi, A.M., Piah, R.M. \& Muchlisin, Z.A. (2016). Biology of Indian Mackerel, Rastrelliger kanagurta (Cuvier, 1817) in the Westren Waters of Aceh. Iranian Journal of Fisheries Sciences. 15(3): 957-972. URL: http://jifro.ir/article-12313-en.html

Asriyana., Rahardjo, M.F., Sukimin, S., Lumban Batu, D. T.F. \& Kartamihardja ES. (2009). Keanekaragaman Ikan di Teluk Kendari. Jurnal Iktiologi Indonesia, 9(2): 97-112. https://doi.org/10.32491/jii.v9i2.183

Asriyana. \& La Sara. (2013). Beberapa Aspek Biologi Reproduksi Ikan Siro (Sardinella longiceps Val.) di Perairan Teluk Kendari, Sulawesi Tenggara. Jurnal Iktiologi Indonesia, 13(1):1-11. DOI, https://doi.org/10.32491/jii.v13i1.107
Asriyana., Halili. \& Irawati, N. (2020). Komposisi Bycatch Perikanan Lele Laut (Famili Plotosidae) di Perairan Teluk Kolono, Sulawesi Tenggara. Jurnal Sains dan Inovasi Perikanan, 4(1): 1-11. http://dx.doi.org/10.33772/jsipi.v4i1.10201

Asriyana, A., Halili, H. \& Irawati N. (2020). Size Structure and Growth Parameters of Striped Eel Catfish (Plotosus lineatus) in Kolono Bay, Southeast Sulawesi, Indonesia. AACL Bioflux, 13(1): 268-279. http://www.bioflux.com.ro/home/volume-13-1$\underline{2020 /}$

Bakhris, V.D., Rahardjo, M.F., Affandi, R. \& Simanjuntak, C.P.H. (2007). Aspek Reproduksi Ikan Motan (Thynnichthys polylepis Bleeker, 1860) di Rawa Banjiran Sungai Kampar Kiri, Riau. Jurnal Iktiologi Indonesia, 7(2): 5359.https://doi.org/10.32491/jii.v7i2.211

Bappeda Konawe Selatan. (2011). Master Plan Pengembangan Minapolitan. [Laporan Akhir]. Badan Perencanaan dan Pembangunan Daerah Konawe Selatan. Kerjasama Bappeda Konawe Selatan dan Lembaga Penelitian Universitas Halu Oleo.

Beyer, J., Myhre, L. P., Sundt, R. C., Meier, S., Tollefsen, K. E., Vabo, R., Klungsoyr, J., \& Sanni, S. (2012). Environmental risk assessment of alkylphenols from offshore produced water on fish reproduction. Mar. Environ. Res., 75: 2-9. http://dx.doi.org/10.1016/j.marenvres.2011.11.01 $\underline{1}$

Bhendarkar, M. P., Naik, S. D., Joshi, H. D., Sonuwane, S. S.\& Hussain T. (2014). Length Frequency Analysis Of Indian Mackerel,Rastrelliger kanagurta (Cuvier, 1817) off Ratnagiri Coast, Maharashtra, India. Ecology Environment and Conservation, 4(20):15491551.http://www.envirobiotechjournals.com/articl e abstract.php?aid $=5460 \&$ iid $=179 \&$ jid $=3$

Brojo, M. \& Sari, R.P. (2002). Biologi Reproduksi Ikan Kurisi (Nemipterus tambuloides Blkr.) yang Didaratkan di Tempat Pelelangan Ikan Labuan, Pandeglang. Jurnal Iktiologi Indonesia, 2(1): 913.https://doi.org/10.32491/jii.v2i1.208

Collette, B.B. \& Nauen, C.E. (1983). FAO Species Catalogue. Vol. 2. Scombrids of the World. An Annotated and Illustrated Catalogue of Tunas, Mackerels, Bonitos and Related Species Known to 
Date. Rome: FAO. FAO Fish. Synop., 125(2):137 p.http://www.fao.org/3/a-ac478e.pdf

de Graaf, M., Machiels, M., Wudneth, T. \& Sibbing, F.A. (2003). Length at Maturity and Gillnet Selectivity of Lake Tana's Barbus Species (Ethiopia): Implication for Management and Conservation. Aquatic Ecosystem Health \& Management, 6(3): 325-336.

https://doi.org/10.1080/14634980301485

Dewanti, R.O.N., Ghofar, A.\& Saputra S.W. (2014). Biological aspects of anchovy (Stolephorus devisi) Caught by Seine Net on Pemalang Waters. Diponegoro Journal of Maquares, 3(4):102111.http://ejournal-s1.undip.ac.id/index.php/ maquares

Effendie, M.I. (2002). Biologi Perikanan. Yogyakarta. Yayasan Pustaka Nusantama. $163 \mathrm{hlm}$. https://marxiv.org/swbrk/download

Erzini K., Gonçalves J.M.S., Bentes, L., Lino, P.G.\&Ribeiro, J. (1998). Species and Size Selectivity in a 'Red' Sea Bream Longline 'Métier' in the Algarve (southern Portugal). Aquatic Living Resources, 11(1):111.https://doi.org/10.1016/S0990-7440(99)800254

Ganga, U. (2010). Investigations on the Biology of Indian Mackerel Rastrelliger kanagurta (Cuvier) Along the Central Kerala Coast With Special Reference to Maturation, Feeding and Lipid Dynamics. [Thesis]. Kochi (IN): Cochin University Of Science And Technology.http://eprints.cmfri.org.in/10453/

Ghosh, S., Rao, M.V.H., Mahesh, V.U., Kumar, M.S., \& Rohit, P. (2016). Fishery, Reproductive Biology And Stock Status of the Indian mackerel Rastrelliger kanagurta (Cuvier, 1817), Landed Along The North- East Coast of India. Indian J. Fish, 63(2): 3341.http://dx.doi.org/10.21077/ijf.2016.63.2.53399 $\underline{-05}$

Juan-Jordá, M.J., Mosqueira, L., Freire, J. \& Dulvy, N.K. (2013). The Conservation and Management of Tunas and Their Relatives: Setting Life History Research Priorities. PLoS ONE 8(8): e70405. https://doi.org/10.1371/journal.pone.0070405.

Kantun, W., Mallawa A. \& Rapi, N. L. (2014). Comparison of the Size Structure of Yellowfin
Tuna Thunnus albacares Caught in Deep and Shallow Seas of Makassar Strait. Jurnal IPTEKS PSP, 1(2):112-128.

DOI: http://dx.doi.org/10.20956/jipsp.v1i2.67

Kantun, W., Kasmi, M., Hadi, S.\& Sugiarti, A. (2018). Reproductive Biology of Indian Mackerel Rastreliger kanagurta (Cuvier, 1816) in Makassar Coastal Waters, South Sulawesi, Indonesia. AACL Bioflux,11(4):1183-

1192.https://www.researchgate.net/publication/32 6876941_Reproductive_biology_of_Indian_mack erel_Rastreliger_kanagurta_Cuvier_1816_in_Ma kassar_coastal_waters_South_Sulawesi_Indonesi a

Karna, S. K. \& Panda, S. (2011). Growth Estimation and Length at Maturity of a Commercially Important Fish Species i. e., Dayscieaena albida (Boroga) in Chilika Lagoon, India. Euro. J. Exp. Bio., 1(2): 8491.www.pelagiaresearchlibrary.com

King M. (1995). Fisheries Biology, Assessment, and Management. London (ID): Fishing News . hlm 341. ISBN: 978-1-405-15831-2. https://www.wiley.com/enus/Fisheries+Biology\%2C+Assessment+and+Ma nagement $\% 2 \mathrm{C}+2 \mathrm{nd}+$ Edition-p-9781405158312

Lagler, K.F., Bardach, J.E., Miller, R.R. \& Passino, D.R.M. (1977). Ichthyology. John Willey and Sons. Inc. new York-London. 506 hal. https://www.amazon.com/Ichthyology-2E-KarlF-Lagler/dp/0471511668

Lowe-McConnell, R.H. (1990). Summary Address: Rare Fish, Problems, Progress and Prospects for Conservation. J. Fish Biol.,37(Suppl.A):263269.https://doi.org/10.1111/j.10958649.1990.tb05061.x

Moresco, A. \&Bemvenuti, M.D. (2006). Reproductive Biology of Silverside Odontesthes argentinensis (Valenciennes) (Atherinopsidae) of Coastal Sea Region of the South of Brazil. Revista Brasileira de Zoologia, 23 (4): 1168 1174.http://www.scielo.br/scielo.php?pid=S0101$\underline{81752006000400025 \& \text { script }=\text { sci_abstract }}$

Muhajirah, W., La Sara.\& Asriyana. (2018). Keanekaragaman dan Hasil Tangkapan Sampingan Jaring Insang di Perairan Lalowaru Kabupaten Konawe Selatan. Jurnal Manajemen Sumber Daya Perairan, 3(1): 43- 
54.http://ojs.uho.ac.id/index.php/JMSP/article/vie $\mathrm{w} / 3550$.

Najamuddin., Mallawa, A., Budiman. \& Indar, M.Y.N. (2004). Pendugaan Ukuran Pertama Kali Matang Gonad Ikan Layang Deles (Decapterus macrosoma Bleeker). Jurnal Sains dan Teknologi, $1: 1-$

8.https://www.academia.edu/1538770/najamuddi n_et_al_2004

Noranarttragoon, P. (2005). Strategies for trawl fisheries bycatch management (REBYC-II CTI; GCP/RAS/269/GFF). Marine Fisheries Research and Development Division Department of Fisheries Bangkok Thailand. 25p. http://www.seafdec.or.th/home/rebyc-cti/keydocuments/projectdocuments?download=83:project-documentstrategies-for-trawl-fisheries-bycatchmanagement-rebyc-ii-cti

Nurhakim, S. (1993). Beberapa Parameter Populasi Ikan Banyar (Rastrelliger kanagurta) di Perairan Laut Jawa. Jurnal Penelitian Perikanan Laut, 81: 64-75.

Oktaviani, D., Matatar, B. \& Nugroho, D. (2013). Keberadaan Ovarium Translucent Sebagai Indikator Musim Pemijahan Ikan Lema (Rastrelliger kanagurta Cuvier, 1816) di Teluk Mayalibit Kepulauan Rajaampat.Bawal,7 (1): 5157.http://dx.doi.org/10.15578/bawal.7.1.2015.51$\underline{57}$

Offem, B.O., Ayotunde, E,O. \& Ikpi, G.U. (2008). Dynamics in the Reproductive of Heterobranchus longifilis Val. (Pisces: 1840) in the Wetlands of Cross River, Nigeria. Research Journal of Fisheries and Hydrobiology, 3(1):2231.https://www.semanticscholar.org/paper/.

Peristiwady, T. (2006). Ikan-Ikan Laut Ekonomis Penting di Indonesia; Petunjuk Identifikasi. LIPI Press. Jakarta. 270 p. http://lipi.go.id/publikasi/ikanikan-laut-ekonomis-penting-di-indonesia-petunjuk-identifikasi/1897

Prihartini, A., Anggoro., Sutrisno.\&Asriyanto. (2007). Biological Performance Analysis of Layang (Decapterus spp.) from the Purse Seine Fishery at the PPN Pekalongan Landing Place. Jurnal Pasir Laut, 3 (1): 61-75. http://eprints.undip.ac.id/4398/.

Reynolds, J.D., Jennings, S. \& Dulvy, N.K. (2001). Life History of Fishes and Populatin Responses to
Exploitation. In: Reynolds JD, Mace GM, Redford KH, Robinson JG (Eds.). Conservation of Exploited Species. Cambridge University Press. Cambridge. pp. 148-168. https://www.researchgate.net/publication/309106 $\underline{873 \text { Life histories_of fishes_and_population_Re }}$ sponses

Sarasati, W. (2017). Dinamika Populasi dan Biologi Reproduksi Multispesies Ikan Kembung (Rastreliger faughni, $R$. kanagurta, $R$. brachysoma) di Perairan Selat Sunda. [Tesis]. Sekolah Pascasarjana Institut Pertanian Bogor. https://repository.ipb.ac.id/handle/123456789/73/ discover.

Senarat, S., Jiraungkoorskul, W. \& Kettratad, J. (2017). Ovarian Histology And Reproductive Health of Short mackerel, Rastrelliger brachysoma (Bleeker, 1851), as Threatened Marine Fish in Thailand. Songklanakarin J. Sci. Technol., 39(2): 225-235. https://rdo.psu.ac.th/sjstweb/journal/392/39-2-11.pdf.

Senarat, S., Kettratad, J. \& Jiraungkoorskul, W. (2015). Morpho-histology of the Reproductive Duct in Short Mackerel Rastrelliger brachysoma (Bleeker, 1851). Advances in Environmental Biology, 9(8): 210-

215.https://www.researchgate.net/publication/301 888037.

Siby, L.S., Rahardjo, M.F. \& Sjafei, D.S. (2009). Biologi Reproduksi Ikan Pelangi Merah (Glossolepis incisus, Weber 1907) di Danau Sentani. Jurnal Iktiologi Indonesia, 9(1):4961.http://dx.doi.org/10.32491/jii.v9i1.201

Simanjuntak, C.P.H. (2007). Reproduksi Ikan Selais, Ompok hypophthalmus (Bleeker) Berkaitan dengan Perubahan Hidromorfologi Perairan di Rawa Banjiran Sungai Kampar Kiri. [Tesis]. Institut Pertanian Bogor. Bogor. https://repository.ipb.ac.id/handle/123456789/416 $\underline{31}$

Soria, M. \& Dagorn, L. (1992). Rappels sur le comportement grégaire. In: Action Incitative Comportement Agrégatif (AICA), Compte-Rendu de Réunion, Doc. Centre ORSTOM Montpellier 9:5-9. http://horizon.documentation.ird.fr/exldoc/pleins textes/divers14-11/36685.pdf

Sritakon, T., Songkaew, N., Chotithammo, S. \& Vechprasit, S. (2011). Reproductive Biology of 
Short Mackerel Rastrelliger brachysoma (Bleeker, 1851) and Indian Mackerel R. kanagurta (Cuvier, 1817) in the Southern Gulf of Thailand. Southern Marine Fisheries Research and Development Center, 79/1 Wichianchom Rd., Bo-Yang, Muang, Songkhla 90000, Thailand. https://www.fisheries.go.th/marine/research/files/ en/142006.pdf

Suwarso, S. \& Hariati, T. (2003). Biologi dan Ekologi Ikan Pelagis Kecil di Pantai Utara Jawa Barat dan Selat Sunda. Jurnal Penelitian Perikanan Indonesia, 9(7): 29-36. http://dx.doi.org/10.15578/jppi.9.7.2003.29-36

Suwarso \& Sadhotomo, B. (1995). Perkembangan Kematangan Gonad Ikan Bentong Selar crumenophthalmus (Carangidae) di Laut Jawa. Jurnal Penelitian Perikanan Indonesia, 2: 77-88. http://ejournal-

balitbang.kkp.go.id/index.php/jppi/article/view/53 $\underline{28 / 4673}$

Suwarso. (2010). Biologi Reproduktif, Preferensi Habitat Pemijahan dan Dugaan Stok Pemijah Ikan Kembung (Rastrelliger brachysoma, FAM. Scombridae) di Pantai Utara Jawa. Jakarta (ID): Badan Riset Perikanan Laut. 23 hlm.

Suwarso, S., Ernawati, T. \& Hariati, T. (2015). Reproductive biology and spawning estimation of short mackerel (Rastrelliger brachysoma) in northern coast of Java. Bawal, 7(1): 9-16. http://dx.doi.org/10.15578/bawal.7.1.2015.9-16 http://ejournal-

balitbang.kkp.go.id/index.php/bawal/article/view/ 199

Suyama, S., Tonnek, S. \& Ahamad, T. (2000). Maturation Cycle of Short Mackerel, Rastrelliger brachysoma, in South Sulawesi, Indonesia. JIRCAS Journal, 8:112.https://www.jircas.go.jp/en/publication/jircas i ournal $/ 8 / 1$

Udupa, K. S. (1986). Statistical method of estimating the size at first maturity in fishes. ICLARM, Metro Manila.Fishbyte, 4(2): 810.https://ideas.repec.org/a/wfi/wfbyte/39513.htm

Zamroni, A., Suwarso. \& Mukhlis, N. A. (2008). Biologi Reproduksi dan Genetik Populasi Ikan Kembung (Rastrelliger brachysoma, Famili Scombridae) di Pantai Utara Jawa. J. Lit. Perikan. In, d. 14(2): 215226. http://ejournalbalitbang.kkp.go.id/index.php/jppi/article/view/36 $\underline{48 / 3140}$

Zamroni, A. \& Ernawati, T. (2019). Population Dynamic and Spawning Potential Ratio of Short Mackerel (Rastrelliger brachysoma Bleeker, 1851) in the Northern Coast of Java. Indonesian Fisheries Research Journal, 25(1): 1-10.http://ejournalbalitbang.kkp.go.id/index.php/ifrj/article/view/67 04/5809 